\title{
Aansprakelijkheid van de (beoogd) curator verduidelijkt
}

\author{
Mr. H.J. de Kloe *
}

\begin{abstract}
Aan de hand van het Ruwaard van Puttenziekenhuis-arrest wordt de aansprakelijkheid van de (beoogd) curator besproken. De auteur concludeert dat de Hoge Raad bij de aansprakelijkheidsnorm voor beoogd curatoren terecht aansluit bij de norm die geldt voor 'gewone' curatoren. Hoewel de Hoge Raad de cassatieklacht hierover heeft verworpen, is de auteur kritischer over aansprakelijkheid van de curator bij niet-nakoming van een negatieve verbintenis.
\end{abstract}

\section{Inleiding}

Op 5 juni 2013 heeft de Stichting Ruwaard van Puttenziekenhuis (hierna: het Ruwaard van Puttenziekenhuis) de rechtbank Den Haag verzocht een of meer beoogd curatoren aan te wijzen. Anderhalve week later, op 24 juni 2013, is het ziekenhuis op eigen aangifte failliet verklaard. Dezelfde dag is overeenstemming bereikt met Spijkenisse Medisch Centrum B.V. (hierna: SMC), een samenwerkingsvehikel van drie omringende ziekenhuizen, over een doorstart. SMC was niet bereid het ziekenhuis door te starten als het verplicht zou worden een toelatingsovereenkomst te sluiten met alle medisch specialisten. $\mathrm{Na}$ de doorstart hebben diverse medisch specialisten hun professie voortgezet als werknemer van SMC of als werknemer of maat van een artsenmaatschap die verbonden was aan een van de omringende ziekenhuizen. De beslissingen van SMC over de positie van medisch specialisten hebben diverse specialisten ertoe aangezet te procederen tegen SMC, de drie omringende ziekenhuizen en de daaraan verbonden artsenmaatschappen. ${ }^{1}$

Sommige specialisten richtten hun pijlen ook op de curatoren. Een uroloog en een radioloog hebben tot aan de Hoge Raad geprocedeerd over de aansprakelijkheid van de curatoren, mede in het licht van hun werkzaamheden als beoogd curator. ${ }^{2}$ In paragraaf 2 geef ik een korte schets van de casus, de

\footnotetext{
Mr. H.J. de Kloe is wetenschappelijk docent ondernemingsrecht en financieel recht bij de sectie Handels- en Ondernemingsrecht \& Financieel Recht van de Erasmus School of Law te Rotterdam.

De tekst voor deze bijdrage is afgesloten op 3 januari 2020.

1. Rb. Rotterdam 18 februari 2015, ECLI:NL:RBROT:2015:1509, JOR 2015/275 (twee oogartsen), Rb. Rotterdam 20 januari 2016, ECLI:NL:RBROT:2016:443 (een anesthesioloog), Hof Den Haag 26 februari 2019, ECLI:NL:GHDHA:2019:347 (twee longartsen), HR 4 oktober 2019, ECLI:NL:HR:2019:1490 (in eerste aanleg en hoger beroep twee urologen, in cassatie één uroloog) en HR 4 oktober 2019, ECLI:NL:HR:2019:1493 (een radioloog).

2. HR 4 oktober 2019, ECLI:NL:HR:2019:1492 (uroloog) en HR 4 okto-
} ber 2019, ECLI:NL:HR:2019:1494 (radioloog). cassatiemiddelen en het oordeel van de Hoge Raad. Omdat de Hoge Raad overweegt dat voor de aansprakelijkheidsnorm die geldt voor beoogd curatoren aansluiting gezocht moet worden bij de norm die geldt voor 'gewone' curatoren, wordt in paragraaf 3 de aansprakelijkheidsnorm voor de curator behandeld. Paragraaf 4 handelt over de aansprakelijkheidsnorm voor beoogd curatoren. In paragraaf 5 en 6 wordt ingegaan op de toepassing van de aansprakelijkheidsnorm in deze specifieke casus. Paragraaf 7 sluit af met een conclusie.

Omdat het inhoudelijke oordeel van de Hoge Raad in beide arresten gelijk is en de feiten grotendeels met elkaar overeenkomen, ga ik in het vervolg van deze bijdrage gemakshalve uit van de procedure die is aangespannen door de uroloog. ${ }^{3}$

\section{Casus, cassatiemiddelen en oordeel Hoge Raad}

Eiser tot cassatie is vrijgevestigd medisch specialist voor urologie. Vanaf 1991 oefent hij zijn praktijk uit in het Ruwaard van Puttenziekenhuis op basis van een toelatingsovereenkomst. Sinds 1 september 1998 makkt de uroloog onderdeel uit van een maatschap. In de toelatingsovereenkomst die is gesloten tussen het ziekenhuis en de uroloog is opgenomen dat de uroloog recht heeft op goodwill ten aanzien van de werkzaamheden die op basis van de toelatingsovereenkomst worden verricht in het Ruwaard van Puttenziekenhuis.

Vanaf 2010 ging het financieel slechter met het ziekenhuis. In 2010 tot en met 2012 werd een negatief financieel resultaat behaald. Deze negatieve financiële situatie werd versterkt doordat de afdeling cardiologie op 13 november 2012 werd gesloten op last van ${ }^{4}$ de Inspectie voor de Gezondheidszorg (IGZ; sinds 1 augustus 2018 Inspectie Gezondheidszorg en Jeugd, IGJ ${ }^{5}$ ). Ook werd het ziekenhuis vanaf 14 november $2012^{6}$ onder verscherpt toezicht gesteld. Door de sluiting van de afdeling cardiologie nam de omzet af en kwam de financiële situatie verder onder druk te staan. Naar aanleiding hiervan is eind 2012 overleg gevoerd met zorgverzekeraars CZ en Achmea en het Maasstad Ziekenhuis (hierna: het Maasstad), het

3. HR 4 oktober 2019, ECLI:NL:HR:2019:1492.

4. Opvallend is dat de afdeling cardiologie volgens het oorzakenonderzoek van de curatoren 'op last van' de IGZ is gesloten, terwijl de afdeling volgens de feitenweergave in de conclusie van A-G Rank-Berenschot (par. 1.1, onder iii) 'in samenspraak met' de Inspectie is gesloten.

5. Stb. 2018, 94 .

6. Aldus het oorzakenonderzoek van de curatoren. Volgens de conclusie van A-G Rank-Berenschot vanaf 1 december 2012. 


\section{Maandblad \\ Ondernemingsrecht}

Ikazia Ziekenhuis (hierna: het Ikazia) en het Van WeelBethesda Ziekenhuis (hierna: het Van Weel-Bethesda). Partijen spraken de intentie uit dat het Ruwaard van Puttenziekenhuis door de drie genoemde ziekenhuizen zou worden overgenomen. Omdat het niet mogelijk was de schulden van het Ruwaard van Puttenziekenhuis te saneren en de overeenkomst te financieren, bleek een overname uiteindelijk echter niet haalbaar.

Vanwege de penibele financiële situatie verzocht het Ruwaard van Puttenziekenhuis op 5 juni 2013 de rechtbank Den Haag een of meer beoogd curatoren aan te wijzen ter voorbereiding van een doorstart in faillissement. De rechtbank heeft twee beoogd curatoren aangewezen en aangegeven dat het doel van de stille voorbereidingsfase was een zo hoog mogelijke opbrengst te realiseren voor de gezamenlijke schuldeisers en maatschappelijke schade zo veel mogelijk te beperken. Omdat de salarissen over de maand juni niet betaald konden worden, heeft het ziekenhuis op 24 juni 2013 eigen aangifte van het faillissement gedaan. Dezelfde dag is het faillissement uitgesproken. Gedurende de stille voorbereidingsfase is onderzoek gedaan naar een doorstart. Twee partijen hebben een bod gedaan op de activa. Een van de bieders was SMC. Alle aandelen in SMC werden gehouden door Zorg in Regio Zuid Coöperatief U.A., een coöperatie waarvan het Maasstad, het Ikazia en het Van Weel-Bethesda lid waren. Op de dag van de faillietverklaring is overeenstemming bereikt met SMC over een doorstart. De curatoren hebben gekozen voor SMC, omdat het bod van SMC 'duidelijk hoger' was dan het andere bod.

SMC wilde het ziekenhuis alleen doorstarten als het niet verplicht zou worden een toelatingsovereenkomst te sluiten met alle medisch specialisten. Wel heeft SMC onder meer met de uroloog een arbeidsovereenkomst gesloten voor de duur van zes maanden, met ingang van 1 juli 2013. De curatoren hebben op 2 juli 2013 de uroloog en de andere medisch specialisten meegedeeld dat zij de toelatingsovereenkomsten niet gestand wilden doen (art. $37 \mathrm{Fw}$ ). De ziekenhuizen hebben op 25 september 2013 een document uitgebracht waarin was opgenomen dat het de maatschappen die actief waren in het Maasstad, het Ikazia en het Van Weel-Bethesda vrijstond de specialisten uit het voormalig Ruwaard van Puttenziekenhuis als maat op te nemen in de maatschap of in loondienst te nemen. Voor de uroloog mocht dit niet baten. Zijn arbeidsovereenkomst met SMC werd niet verlengd en hij werd evenmin in de gelegenheid gesteld als maat of in loondienst toe te treden tot een artsenmaatschap.

De uroloog stelt de curatoren, mede in het licht van hun werkzaamheden als beoogd curator, persoonlijk (pro se) aansprakelijk voor de door hem geleden schade. Deze bestaat uit gederfde goodwill, gederfde inkomsten en pensioenschade. De uroloog verwijt de curatoren onder meer dat zij zijn praktijk hebben overgedragen, althans dat zij hebben gefaciliteerd dat SMC zijn praktijk heeft voortgezet, zonder daarvoor een ver- goeding te betalen aan de uroloog. Ook stelt de uroloog dat de curatoren hem ten onrechte niet hebben betrokken bij (de voorbereiding van) de doorstart en zijn belangen hebben veronachtzaamd. ${ }^{7}$ De vorderingen tegen de curatoren zijn zowel in eerste aanleg ${ }^{8}$ als in hoger beroep 9 afgewezen. Het gerechtshof Den Haag stelt bij de beoordeling voorop dat de aansprakelijkheid van de curatoren beoordeeld moet worden aan de hand van de maatstaven die de Hoge Raad voor het eerst heeft geformuleerd in het Maclou-arrest en in latere arresten heeft uitgewerkt. ${ }^{10}$ In beginsel komt curatoren een grote mate van vrijheid toe bij de uitoefening van hun taak. De curatoren hebben ervoor gekozen een transactie aan te gaan met SMC, onder meer omdat SMC het hoogste bod had uitgebracht. Mede in het licht van het gegeven dat SMC niet bereid was de transactie aan te gaan als het een toelatingsovereenkomst moest sluiten met alle medisch specialisten, hebben de beoogd curatoren naar het oordeel van het hof niet onrechtmatig gehandeld jegens de uroloog. Er bestond geen verplichting voor de (beoogd) curatoren om de medisch specialisten te betrekken bij de onderhandelingen met SMC. Ook waren de (beoogd) curatoren niet verplicht ervoor zorg te dragen dat SMC een arbeids- of toelatingsovereenkomst zou aanbieden aan de medisch specialisten of een goodwillvergoeding aan hen zou aanbieden. ${ }^{11}$

Het cassatiemiddel bestaat uit drie onderdelen. In de eerste plaats zou de aansprakelijkheid van de beoogd curatoren niet moeten worden beoordeeld aan de hand van de Maclou-norm. Bij de aansprakelijkheid van de curatoren moet rekening worden gehouden met het feit dat zij voorafgaand aan het faillissement zijn aangesteld als beoogd curator. De aansprakelijkheid van curatoren die na een stille voorbereidingsfase worden aangesteld tot curator zou volgens het cassatiemiddel niet moeten worden beoordeeld aan de hand van de Maclou-norm, maar aan de hand van de norm die geldt voor advocaten en vergelijkbare beroepsbeoefenaren. Ten tweede wordt aangevoerd dat de verplichtingen ten aanzien van de goodwill die voortvloeien uit de toelatingsovereenkomst, regels zijn die nagekomen moeten worden door de curatoren. De curatoren hadden niet de vrijheid om de toelatingsovereenkomst niet na te komen. Tot slot wordt een aantal klachten aangevoerd tegen het oordeel van het hof dat de (beoogd) curatoren een ruime mate van vrijheid hadden bij het vormgeven van de doorstart en niet onrechtmatig hebben gehandeld jegens de uroloog.

In navolging van A-G Rank-Berenschot verwerpt de Hoge Raad het cassatieberoep. De Hoge Raad overweegt dat, bij gebrek aan een wettelijke regeling over de stille voorberei-

7. Hof Den Haag 28 november 2017, ECLI:NL:GHDHA:2017:3385, r.o. 2.7.

8. Rb. Rotterdam 20 januari 2016, ECLI:NL:RBROT:2016:444.

9. Hof Den Haag 28 november 2017, ECLI:NL:GHDHA:2017:3385.

10. HR 19 april 1996, ECLI:NL:HR:1996:ZC2047, NJ 1996/727. Zie over de Maclou-norm par. 3 van deze bijdrage.

11. Hof Den Haag 28 november 2017, ECLI:NL:GHDHA:2017:3385, r.o. 2.9 en 2.10 . 
dingsfase (pre-pack), voor de positie en taak van de beoogd curator betekenis toekomt aan de aanwijzingen van de rechter of beoogd rechter-commissaris en de INSOLAD Praktijkregels beoogd curator. Daarnaast is van belang dat een beoogd curator wordt aangesteld om het faillissement voor te bereiden. Dit brengt met zich dat hij zich moet laten leiden door de belangen van de gezamenlijke schuldeisers en rekening moet houden met maatschappelijke belangen. $\mathrm{Nu}$ de tak van de beoogd curator overeenkomt met die van de 'gewone' curator, dient voor de beoordeling van zijn aansprakelijkheid aangesloten te worden bij de Maclou-norm. Het hof heeft daarmee de juiste aansprakelijkheidsmaatstaf toegepast. Daarnaast overweegt de Hoge Raad dat bij de aansprakelijkheid van de 'gewone' curator betekenis toekomt aan zijn handelen als beoogd curator gedurende de stille voorbereidingsfase. Dit is door het hof onderkend en leidt daarom niet tot cassatie. De overige cassatieklachten worden verworpen onder toepassing van artikel 81 lid 1 Wet RO.

\section{Norm aansprakelijkheid curator}

In het Maclou-arrest heeft de Hoge Raad geoordeeld dat de norm waaraan de persoonlijke aansprakelijkheid van een curator getoetst moet worden, moet aansluiten bij diens positie. Een curator moet vaak op korte termijn beslissingen nemen waarbij hij uiteenlopende belangen, die soms tegenstrijdig zijn aan elkaar, moet behartigen. Onder de belangen waarmee de curator rekening moet houden, vallen belangen van maatschappelijke aard. Gelet hierop behoort een curator te handelen 'zoals in redelijkheid mag worden verlangd van een over voldoende inzicht en ervaring beschikkende curator die zijn taak met nauwgezetheid en inzicht verricht'. ${ }^{12}$ Aan deze zorgvuldigheidsnorm wordt het handelen van de curator getoetst. In het arrest Prakke/Gips heeft de Hoge Raad de Maclou-norm verder uitgewerkt. Zolang een curator bij de uitoefening van zijn taak niet gebonden is aan regels, heeft hij een ruime mate van beleidsvrijheid. Aan de Maclou-norm moet terughoudend worden getoetst.

'Voor persoonlijke aansprakelijkheid is immers vereist dat de curator ook persoonlijk een verwijt kan worden gemaakt van zijn handelen. Daarvoor is vereist dat hij gehandeld heeft terwijl hij het onjuiste van zijn handelen inzag dan wel redelijkerwijs behoorde in te zien.' ${ }^{13}$

Is een curator gebonden aan regels, dan heeft hij geen beleidsvrijheid. Hoewel alle regels die gelden voor de curator gebaseerd zijn op (het stelsel van) de wet, ${ }^{14}$ kan naast handelen in strijd met een wettelijke bepaling ${ }^{15}$ een aantal typen regels worden onderscheiden. Een eerste type is een beschikking van

12. HR 19 april 1996, ECLI:NL:HR:1996:ZC2047, NJ 1996/727, r.o. 3.6.

13. HR 16 december 2011, ECLI:NL:HR:2011:BU4204, NJ 2012/515, r.o. 3.4.2.

14. Vgl. F.M.J. Verstijlen, De faillissementscurator (diss. Tilburg), Deventer: W.E.J. Tjeenk Willink 1998, p. 229.

15. R. Mulder, De persoonlijke aansprakelijkheid van de curator: oppassen geblazen, steeds meer 'regels'! Een overzicht van de stand van zaken, TvI 2019/5, par. 2.1. de rechter-commissaris. Voor een aantal in de Faillissementswet aangegeven handelingen, zoals het opzeggen van arbeidsovereenkomsten (art. 68 lid 3 jo. art. $40 \mathrm{Fw}$ ) en het onderhands verkopen van activa (art. 176 lid $1 \mathrm{Fw}$ ), heeft de curator machtiging of toestemming van de rechter-commissaris nodig. Daarnaast kunnen de in artikel 69 lid 1 Fw genoemde partijen een bevel van de rechter-commissaris uitlokken, inhoudende dat de curator een bepaalde handeling verricht of nalaat. Wijst de rechter-commissaris een beschikking, dan heeft de curator zich hieraan te houden en heeft hij ten aanzien van de inhoud van de beschikking geen beleidsvrijheid. ${ }^{16}$

Een tweede type is jurisprudentie. In het arrest Rabobank/ Verdonk q.q. ${ }^{17}$ heeft de Hoge Raad overwogen dat de curator geen vrijheid heeft om af te wijken van de regels die de Hoge Raad heeft gegeven in het arrest Hamm q.q./ABN AMRO. ${ }^{18}$ Het oordeel van de Hoge Raad is toegesneden op jurisprudentie over inning van stil verpande vorderingen, maar het arrest is breder te trekken. Als jurisprudentie van de Hoge Raad een bepaalde gedragslijn voorschrijft, dan moet de curator zich aan die lijn houden. ${ }^{19}$ Het is niet duidelijk of ook lagere jurisprudentie aangemerkt kan worden als een regel in de zin van Prakke/Gips. Dat is in ieder geval niet aan de orde als geen duidelijke lijn te ontwaren is in lagere jurisprudentie. Is in lagere rechtspraak geen verdeeldheid over de wijze waarop een curator zich in een specifiek geval moet gedragen, dan is verdedigbaar dat hieruit een regel voortvloeit in de zin van Prakke/ Gips en moet de curator in ieder geval op zijn tellen passen.

Een derde type regels dat de Hoge Raad geeft, is een verbintenisrechtelijke verplichting. In het Berzona-arrest overwoog de Hoge Raad dat de curator niet de bevoegdheid heeft een overeenkomst actief niet na te komen. ${ }^{20}$ Dit oordeel is nader toegelicht in het arrest Credit Suisse/Jongepier q.q.: uit artikel 37 Fw blijkt dat de curator bevoegd is een overeenkomst passief niet na te komen, maar de curator heeft niet de bevoegdheid een prestatie actief ongedaan te maken of een prestatie tot dulden of nalaten te beëindigen. ${ }^{21}$ Een verbintenis tot dulden of nalaten is, zo volgt uit het arrest De Klerk q.q. \& El Ayoubi/X, een regel in de zin van Prakke/Gips. ${ }^{22}$ Omdat in cassatie is aangevoerd dat de goodwillverplichting een regel is van het derde type, kom ik hierop in paragraaf 5 terug.

Overtreedt de curator een regel, dan is hij persoonlijk aansprakelijk jegens degenen die de overtreden regel beoogt te beschermen, tenzij hem ondanks het overtreden van de regel

16. HR 27 november 1998, ECLI:NL:HR:1998:ZC2793, NJ 1999/685 (Komdeur/Nederlandse Antillen), r.o. 4.5.2 en 4.5.8.

17. HR 5 februari 2016, ECLI:NL:HR:2016:199, NJ 2016/187.

18. HR 30 oktober 2009, ECLI:NL:HR:2009:BJ0861, NJ 2010/96.

19. Zie ten aanzien van regels uit de jurisprudentie van de Hoge Raad over onverschuldigde betaling bijv. Hof 's-Hertogenbosch 13 augustus 2019, ECLI:NL:GHSHE:2019:3019, r.o. 3.8.2.

20. HR 11 juli 2014, ECLI:NL:HR:2014:1681, NJ 2014/407, r.o. 3.6.4.

21. HR 23 maart 2018, ECLI:NL:HR:2018:424, NJ 2018/290, r.o. 3.5.2 en 3.5.3.

22. HR 9 november 2018, ECLI:NL:HR:2018:2067, NJ 2018/464, r.o. 3.5.3. 


\section{Maandblad}

Ondernemingsrecht

geen persoonlijk verwijt treft. ${ }^{23}$ In vergelijkbare zin oordeelde de Hoge Raad dat een bestuurder in beginsel een ernstig verwijt treft en hij tegenover de vennootschap op grond van artikel 2:9 BW aansprakelijk is als het bestuur in strijd heeft gehandeld met statutaire bepalingen die de vennootschap beogen te beschermen. Een bestuurder kan echter feiten en omstandigheden aanvoeren op grond waarvan aangenomen kan worden dat hem geen ernstig verwijt treft. ${ }^{24}$ Het lijkt erop dat ook bij de persoonlijke aansprakelijkheid van de curator de stelplicht dat niet persoonlijk verwijtbaar is gehandeld op de curator rust. $^{25}$

Ook voor het overige zijn er parallellen te trekken tussen bestuurdersaansprakelijkheid en persoonlijke aansprakelijkheid van de curator. De terminologie van de Hoge Raad bij het formuleren van de aansprakelijkheidsmaatstaf is anders, maar wel vergelijkbaar. Bij de curator gaat het om een persoonlijk verwijt, terwijl een bestuurder ${ }^{26}$ (persoonlijk ${ }^{27}$ ) ernstig verwijtbaar gehandeld moet hebben. Assink meent dat uit dit onderscheid in terminologie volgt dat de wijze van toetsing door de rechter verschillend is. Naar zijn mening kent de toetsing van aansprakelijkheid van bestuurders twee toetsingsrondes: een eerste ronde waarin getoetst wordt of verwijtbaar is gehandeld, en een tweede ronde waarin getoetst wordt of deze verwijtbaarheid voldoende ernstig is om aansprakelijkheid aan te nemen. Bij curatorenaansprakelijkheid is sprake van één toetsingsronde. Wel voegt Assink daaraan toe dat beide maatstaven veelal niet tot een andere uitkomst hoeven te leiden. ${ }^{28}$ In de rechtspraak wordt dit onderscheid niet altijd gemaakt. Ook bij curatorenaansprakelijkheid wordt in de lagere rechtspraak regelmatig getoetst of de curator een (voldoende) ernstig persoonlijk verwijt treft. ${ }^{29}$ Wat hier verder ook van zij, het is in ieder geval duidelijk dat de aansprakelijkheid van een curator - net als die van een bestuurder - in beginsel terughoudend getoetst moet worden.

\section{Maclou-norm en de beoogd curator}

Totdat het hier besproken arrest werd gewezen, was onduidelijk of het handelen van een beoogd curator op dezelfde wijze beoordeeld diende te worden. De Hoge Raad geeft hier duidelijkheid over door te overwegen dat voor de beoordeling van de aansprakelijkheid van de beoogd curator aansluiting

23. HR 9 november 2018, ECLI:NL:HR:2018:2067, NJ 2018/464, r.o. 3.5.2 en 3.5.4.

24. HR 29 november 2002, ECLI:NL:HR:2002:AE7011, NJ 2003/455 (Berghuizer Papierfabriek), r.o. 3.4.5.

25. Vgl. de annotatie van Verstijlen onder HR 9 november 2018, ECLI:NL:HR:2018:2067, NJ 2018/464, par. 7.

26. In het geval van aansprakelijkheid op grond van art. 2:9 BW het bestuur, omdat dit een collectieve aansprakelijkheid betreft.

27. Bij aansprakelijkheid op grond van art. 6:162 BW, zie het standaardarrest Ontvanger/Roelofsen, HR 8 december 2006, ECLI:NL:HR: 2006:AZ0758, NJ 2006/659, r.o. 4.5.

28. B.F. Assink, Curator- en bestuurdersaansprakelijkheid in juxtapositie, AA 2016, afl. 11, p. 855-866.

29. Zie bijv. Rb. Rotterdam 24 september 2014, ECLI:NL:RBROT: 2014:7899, r.o. 4.12; Hof Amsterdam 29 september 2015, ECLI:NL:GHAMS:2015:4031, r.o. 3.7; Rb. Limburg 23 maart 2016, ECLI:NL:RBLIM:2016:5346, r.o. 4.1 en 4.2. gezocht moet worden bij de Maclou-norm. De beoogd curator bereidt immers een faillissement voor en moet zich, net als de 'gewone' curator, laten leiden door de belangen van de gezamenlijke schuldeisers en rekening houden met belangen van maatschappelijke aard. Bij de beoordeling van de aansprakelijkheid van een beoogd curator moet daarom worden onderzocht 'of de beoogd curator heeft gehandeld zoals in redelijkheid mag worden verlangd van een over voldoende inzicht en ervaring beschikkende beoogd curator die zijn taak met nauwgezetheid en inzet verricht'. ${ }^{30}$

Deze overweging van de Hoge Raad sluit aan bij de toelichting op de ontwerptekst van het wetsvoorstel Wet continuïteit ondernemingen I (WCO I), waarin een wettelijke basis wordt gecreëerd voor de stille voorbereidingsfase. In deze ontwerptoelichting was, onder verwijzing naar de Maclou-norm, opgenomen dat voor de persoonlijke aansprakelijkheid van een beoogd curator vereist is dat de beoogd curator een persoonlijk verwijt treft. $^{31}$ De verwijzing naar de Maclou-norm is geschrapt in de memorie van toelichting bij het wetsvoorstel dat is ingediend bij de Tweede Kamer. ${ }^{32}$ De reden hiervoor lijkt niet te zijn dat de minister anders is gaan denken over de aansprakelijkheidsnorm voor de beoogd curator, maar dat de verwijzing naar de Maclou-norm was opgenomen in de toelichting bij een artikellid - waarin was opgenomen dat de beoogd curator onder meer zou kunnen verklaren dat hij een voorgenomen rechtshandeling als curator niet zou vernietigen op grond van pauliana - dat in het daadwerkelijke wetsvoorstel is geschrapt. ${ }^{33}$ In de nota naar aanleiding van het verslag is door de minister opnieuw verwezen naar de Maclounorm. ${ }^{34}$ Ook in de literatuur werd ervan uitgegaan dat de Maclou-norm van overeenkomstige toepassing is op de persoonlijke aansprakelijkheid van de beoogd curator. ${ }^{35}$

Het geeft de nodige duidelijkheid dat ook de Hoge Raad oordeelt dat voor aansprakelijkheid van de beoogd curator aansluiting gezocht moet worden bij de Maclou-norm. Omdat sprake is van een open norm, is hiermee echter niet alles gezegd. ${ }^{36}$ In de literatuur wordt verschillend gedacht over de persoonlijke aansprakelijkheid van de beoogd curator in verhouding tot de persoonlijke aansprakelijkheid van de 'gewone' curator. Van Zanten meent dat de beoogd curator een groter

30. HR 4 oktober 2019, ECLI:NL:HR:2019:1492, r.o. 3.2.3.

31. Ontwerp-MvT Wet continuïteit ondernemingen I, p. 23, www.internet consultatie.nl/wet_continuiteit_ondernemingen_i.

32. Kamerstukken II 2014/15, 34218, nr. 3 .

33. H.J.M. van Dal, D.J.C. Nuijten \& F.A. van Tilburg, Het spanningsveld bij bestuurdersaansprakelijkheid en ansprakelijkheid van de beoogd curator in de stille voorbereidingsfase, TvOB 2016, afl. 4, p. 130-131.

34. Kamerstukken II 2014/15, 34218, nr. 6, p. 24-25.

35. Zie bijv. N.W.A. Tollenaar, Van pre-pack naar stille bewindvoering: een nuttige rechtsfiguur in de maak, FIP 2013, afl. 6, p. 202-213, par. 5; M.H.S. Verhoeven, De aansprakelijkheid van de (beoogd) curator, TAV 2016/31 en Van Dal, Nuijten \& Van Tilburg 2016. Zie impliciet ook M.R. van Zanten, De beoogd curator, uitgegroeid van fly on the wall tot spin in het web, TvI 2015/35.

36. F.M.J. Verstijlen, Pre-packing in the Netherlands. De beoogde 'beoogd curator', NJB 2014/803. Zie ook de annotatie van Verstijlen onder HR 4 oktober 2019, ECLI:NL:HR:2019:1494, NJ 2019/461, par. 9. 
risico loopt op persoonlijke aansprakelijkheid dan de curator, omdat op de beoogd curator een zwaardere verantwoordelijkheid rust. Daar waar schuldeisers in faillissement op verschillende manieren voor zichzelf kunnen opkomen, moeten zij erop vertrouwen dat hun belangen gedurende de stille voorbereidingsfase door de beoogd curator worden behartigd. Door het gebrek aan transparantie tijdens de stille voorbereidingsfase kunnen schuldeisers immers niet zelf hun belangen behartigen. ${ }^{37}$ Tollenaar stelt daarentegen dat het aansprakelijkheidsrisico van de beoogd curator beperkt is, omdat de beoogd curator - in tegenstelling tot de gewone curator - niet zelf handelt. Staat de schuldenaar op het punt derden schade toe te brengen, dan heeft de beoogd curator weinig mogelijkheden dit te voorkomen. Volgens Tollenaar moet de beoogd curator de schuldenaar dan aanwijzingen geven om de schade te voorkomen en terugtreden als deze aanwijzingen niet opgevolgd worden. ${ }^{38}$

Mijns inziens moet de beoogd curator die weet of behoort te weten dat een voorgenomen handeling van de schuldenaar schade toebrengt aan derden, deze handeling proberen te voorkomen. Volgt de schuldenaar de aanwijzingen van de beoogd curator niet op, dan is het aansprakelijkheidsrisico van de beoogd curator beperkt. De beoogd curator heeft immers geen bevoegdheden de schuldenaar te dwingen zijn aanwijzingen op te volgen. Weliswaar kan de beoogd curator zich terugtrekken (op basis van het wetsvoorstel WCO I de rechtbank verzoeken de aanwijzing van de beoogd curator in te trekken ${ }^{39}$ ), maar daarmee kan niet worden voorkomen dat de schuldenaar derden schade berokkent.

In de literatuur wordt met name gewezen op het risico dat de beoogd curator loopt als het bestuur tijdens de stille voorbereidingsfase de Beklamel-norm overtreedt. Gaat het bestuur een verplichting aan terwijl het weet of behoort te weten dat de vennootschap die verplichting niet kan nakomen en geen verhaal biedt voor de schade, dan zijn de bestuurders in beginsel op grond van artikel 6:162 BW aansprakelijk tegenover de wederpartij. ${ }^{40}$ De beoogd curator die dit lijdzaam laat gebeuren, loopt ook het risico hiervoor aansprakelijk te worden gehouden. ${ }^{41}$ Ook hiervoor geldt mijns inziens dat het enkele feit dat de curator weet of behoort te weten dat de Beklamelnorm wordt overtreden, niet leidt tot aansprakelijkheid, omdat de curator het niet in zijn macht heeft een dergelijke overtreding te voorkomen. De beoogd curator loopt pas een aansprakelijkheidsrisico als hij in een dergelijk geval geen poging onderneemt een overtreding te voorkomen, door geen

37. Van Zanten 2015 onder verwijzing naar Kamerstukken II 2014/15, 34218 , nr. 3, p. 5.

38. Tollenaar 2013 , par. 5 .

39. Kamerstukken I 2015/16, 34218, A, art. 366 lid 1 Fw (nieuw).

40. HR 6 oktober 1989, ECLI:NL:HR:1989:AB9521, NJ 1990/286 (Beklamel). Zie ook HR 8 december 2006, ECLI:NL:HR:2006:AZ0758, NJ 2006/659 (Ontvanger/Roelofsen).

41. Tollenaar 2013, par. 5.3; Verstijlen 2014, p. 1104; Van Dal, Nuijten \& Van Tilburg 2016, par. 4.2. aanwijzing te geven aan het bestuur om niet op de voorgenomen manier te handelen.

Wordt een beoogd curator in een faillissement dat volgt op de stille voorbereidingsfase aangesteld tot curator, dan werkt zijn handelen als beoogd curator naar het oordeel van de Hoge Raad door in de aansprakelijkheidsnorm van de curator tijdens faillissement. ${ }^{42}$ Dit spreekt voor zich, omdat de aansprakelijkheid van de curator wordt beoordeeld aan de hand van alle omstandigheden van het geval. Dat de curator het faillissement heeft kunnen voorbereiden, is een relevante omstandigheid. Hierdoor heeft de curator langer de tijd om informatie te vergaren, potentiële kopers te benaderen en beslissingen te nemen. Neemt de curator tijdens faillissement onjuiste beslissingen omdat hij de stille voorbereidingsfase niet heeft benut om het faillissement goed voor te bereiden, dan is hij eerder aansprakelijk. ${ }^{43}$

\section{Goodwillvergoeding die voortvloeit uit een overeenkomst als regel}

Het - in paragraaf 3 beschreven - oordeel van de Hoge Raad dat de curator niet bevoegd is een prestatie tot dulden of nalaten te beëindigen, heeft tot kritiek geleid in de literatuur. Het onderscheid tussen een verbintenis tot doen en een verbintenis tot nalaten is niet altijd eenvoudig te maken. Dit lijkt de mogelijkheid te bieden een verbintenis zo te formuleren dat sprake is van een verbintenis tot dulden of nalaten, zodat de curator niet bevoegd is te wanpresteren. ${ }^{44}$ Wibier geeft het voorbeeld van een betalingsverplichting die zo wordt geformuleerd dat de schuldenaar moet dulden dat de schuldeiser van een automatische incasso gebruikmaakt. ${ }^{45} \mathrm{Ik}$ kan mij niet voorstellen dat de curator een dergelijke verbintenis moet respecteren, maar onduidelijk is waar de grens ligt. Dat is dan ook het grootste bezwaar tegen het oordeel van de Hoge Raad in De Klerk q.q. \& El Ayoubi/X, dat een verbintenis tot dulden of nalaten een regel is als bedoeld in Prakke/Gips. Het zorgt voor rechtsonzekerheid en zadelt de curator op met een groot aansprakelijkheidsrisico. ${ }^{46}$

In de kwestie van de uroloog tegen de curatoren van het Ruwaard van Puttenziekenhuis verwerpt de Hoge Raad de stelling dat de goodwillverplichtingen die voortvloeien uit de toelatingsovereenkomst regels zijn in de zin van Prakke/Gips onder toepassing van artikel 81 Wet RO. Ook A-G RankBerenschot is hier kort over. $\mathrm{Na}$ een vrij lange aanloop stelt de

42. HR 4 oktober 2019, ECLI:NL:HR:2019:1492, r.o. 3.2.4.

43. Verstijlen 2014, p. 1103-1104; annotatie Verstijlen onder HR 4 oktober 2019, ECLI:NL:HR:2019:1494, NJ 2019/461, par. 10.

44. R.M. Wibier, Berzona is geen vergissing, wat nu?, MvV 2018, afl. 12, p. 379-382; T.T. van Zanten, Negatieve verplichtingen in faillissement, TvI 2019/3.

45. Wibier 2018, p. 381 .

46. Zie bijv. de noot van F.J.M. Verstijlen onder HR 9 november 2018, ECLI:NL:HR:2018:2067, NJ 2018/464 (De Klerk q.q. \& El Ayoubi/X), de noot van A.J. Tekstra onder hetzelfde arrest in JOR 2019/26 en W.H. van Boom, Actief en passief wanpresteren van de faillissementscurator. Credit Suisse in het licht van Blaauboer/Berlips, WPNR 2019, afl. 7232, p. 248-255. 


\section{Maandblad}

Ondernemingsrecht

A-G in een aantal zinnen dat het recht op (vergoeding van) goodwill niet kwalificeert als een verplichting tot nalaten of een andere regel in de zin van Prakke/Gips. $\mathrm{Nu}$ in de toelatingsovereenkomst is opgenomen dat de medisch specialist 'recht heeft op' goodwill bij een overdracht van de praktijk, is dit in overeenstemming met de lijn van de Hoge Raad.

Het is de vraag wat de uitkomst was geweest indien de goodwillverplichting expliciet als verbintenis tot dulden of nalaten was geformuleerd. Men had bijvoorbeeld kunnen afspreken dat het ziekenhuis moest nalaten (het relevante deel van) de onderneming over te dragen zonder gelijktijdige overdracht van de toelatingsovereenkomst aan de verkrijger of zonder directe en integrale vergoeding van de goodwill. Omdat ook in dat geval feitelijk sprake is van een positieve verplichting - de curator kan zich immers aan de verplichting onttrekken door iets niet te doen - verwacht ik dat de curatoren ook dan niet aansprakelijk zouden zijn, maar het had de afweging voor de curatoren wel lastiger gemaakt.

Mij spreekt de benadering dat een verbintenisrechtelijke verplichting tot dulden of nalaten een regel is in de zin van Prakke/Gips niet aan. Het gevaar bestaat dat de curator een groot deel van zijn tijd kwijt is aan het evalueren en afdekken van zijn eigen aansprakelijkheidsrisico's en daarmee minder tijd heeft om de boedel op een ordentelijke wijze af te wikkelen. Verheul stelt (in een mijns inziens overtuigend en lezenswaardig betoog) dat de curator alleen dan een verbintenis tot dulden of nalaten zou moeten respecteren, als hij een rechtsvordering moet instellen tegen de wederpartij om een dergelijke verbintenis te beëindigen. In dat geval kan de wederpartij de verweermiddelen die zij tegen de schuldenaar kan opwerpen ook tegenwerpen aan de curator. Heeft de curator zelf de beëindiging van een verbintenis tot dulden of nalaten in de hand, dan zou hij bevoegd moeten zijn deze verbintenis niet na te komen. ${ }^{47}$ Deze benadering spreekt mij meer aan, omdat zij zorgt voor duidelijkheid voor de curator.

\section{Overdragen rechtsverhouding medisch specialisten}

$\mathrm{Nu}$ de goodwillverplichting geen regel is in de zin van Prakke/ Gips, komt de curator beleidsvrijheid toe. Deze beleidsvrijheid is niet onbegrensd, omdat de curator primair als taak heeft de belangen van de gezamenlijke schuldeisers te behartigen en bij zijn taakvervulling moet streven naar een zo hoog mogelijke opbrengst voor de gezamenlijke schuldeisers. ${ }^{48}$ De curator mag bij de vervulling van zijn taak belangen van maatschappelijke aard voorrang verlenen boven belangen van individuele

47. E.F. Verheul, De beperkte reikwijdte van het keuzerecht van de curator, TvI 2019/16, in het bijzonder par. 4 en 5.

48. O.a. HR 5 maart 1920, ECLI:NL:HR:1920:98, NJ 1920, p. 343 en HR 23 december 1994, ECLI:NL:HR:1994:ZC1590, NJ 1996/628 (Notarissen THB II), r.o. 4.3.2. schuldeisers, ${ }^{49}$ maar over het antwoord op de vraag of de curator dergelijke belangen ook mag laten prevaleren boven de belangen van de gezamenlijke schuldeisers is de literatuur verdeeld..$^{50}$ Als de curator belangen van maatschappelijke aard mag laten prevaleren boven de belangen van de gezamenlijke schuldeisers, moet hij een belangenafweging maken.

Het is de vraag of het recht van een medisch specialist op een goodwillvergoeding te kwalificeren is als belang van maatschappelijke aard. In beginsel is het recht op betaling van een geldsom mijns inziens niet als zodanig te kwalificeren. Dat is anders ten aanzien van de toelatingsovereenkomst van de medisch specialisten. In Sigmacon II heeft de Hoge Raad expliciet overwogen dat de continuïteit van de onderneming en werkgelegenheid gelden als belangen van maatschappelijke aard. ${ }^{51}$ Deze overweging is niet direct van toepassing op de positie van de medisch specialisten, omdat het in de overweging van de Hoge Raad specifiek lijkt te gaan over de onderneming die door de schuldenaar wordt gedreven en de werkgelegenheid van werknemers van de schuldenaar. Medisch specialisten die in maatschapsverband werkzaam zijn in een ziekenhuis hebben geen arbeidsovereenkomst met dat ziekenhuis. Ook staat hun onderneming tot op zekere hoogte los van het ziekenhuis. Desondanks zijn de continuïteit van een artsenmaatschap en de werkgelegenheid van medisch specialisten bij het faillissement van een ziekenhuis ook een belang van maatschappelijke aard.

Uit de feitenweergave blijkt dat SMC het hoogste bod had uitgebracht en niet bereid was een toelatingsovereenkomst te sluiten met alle medisch specialisten. Gelet op de primaire taak van de curator om de belangen van de gezamenlijke schuldeisers te behartigen, ligt het voor de hand dat de curatoren dit bod hebben geaccepteerd. Uit de feitenweergave blijkt niet hoeveel hoger het bod van SMC was ten opzichte van de andere bieder en of de andere bieder wél bereid was een toelatingsovereenkomst te sluiten met de medisch specialisten. Was ook de andere bieder daartoe niet bereid, dan was het voor de curatoren niet eens mogelijk om ervoor te zorgen dat de toelatingsovereenkomst was overgenomen door een doorstarter. Was de andere bieder daartoe wel bereid, dan is het aan de curatoren om de betrokken belangen tegen elkaar af te wegen.

Juist in dergelijke situaties heeft de curator beleidsvrijheid. Hadden de curatoren die beleidsvrijheid niet, dan zouden zij

49. HR 24 februari 1995, ECLI:NL:HR:1995:ZC1643, NJ 1996/472 (Sigmacon II), r.o. 3.5; HR 19 april 1996, ECLI:NL:HR:1996:ZC2047, NJ 1996/727 (Maclou/Curatoren van Schuppen), r.o. 3.5.2 en 3.6; HR 19 december 2003, ECLI:NL:HR:2003:AN7817, NJ 2004/293 (Curatoren Mobell/Interplan), r.o. 3.5.2.

50. Zie voor een positief antwoord op deze vraag bijv. F. Kemp, Gezocht: kranige curatoren met maatschappelijk besef, in: Ph.W. Schreurs e.a. (red.), De gereedschapskist van de curator (INSOLAD Jaarboek 2015), Deventer: Wolters Kluwer, p. 503-514 en voor een negatief antwoord B. Wessels, Insolventierecht IV. Bestuur en beheer na faillietverklaring, Deventer: Wolters Kluwer 2015, nr. 4223.

51. HR 24 februari 1995, ECLI:NL:HR:1995:ZC1643, NJ 1996/472, r.o. 3.5 


\section{Maandblad}

door de kat (de medisch specialisten) of door de hond (de gezamenlijke schuldeisers) gebeten kunnen worden. Pakt de belangenafweging uit in het voordeel van de gezamenlijke schuldeisers, dan stellen de medisch specialisten de curatoren aansprakelijk. Zijn de curatoren van mening dat de belangen van de medisch specialisten zwaarder wegen, dan worden zij aansprakelijk gesteld door de schuldeisers. Het is mijns inziens daarom terecht dat het hof de aansprakelijkheidsvordering tegen de curatoren heeft afgewezen en dat de Hoge Raad het arrest van het hof in stand heeft gelaten.

\section{Conclusie}

De Hoge Raad heeft een helder arrest gewezen over de aansprakelijkheidsnorm voor beoogd curatoren. Dat de aansprakelijkheidsnorm voor beoogd curatoren ansluit bij de norm die geldt voor 'gewone' curatoren, komt niet als een verrassing. Ook het oordeel van de Hoge Raad dat bij de beoordeling van de aansprakelijkheid van de curator betekenis toekomt aan zijn handelen tijdens de stille voorbereidingsfase, verrast niet.

Zoals altijd het geval is bij open normen moet de aansprakelijkheidsnorm voor beoogd curatoren worden ingevuld aan de hand van de omstandigheden van het geval. Duidelijk is in ieder geval dat het handelen van de (beoogd) curator terughoudend getoetst moet worden, omdat de (beoogd) curator beleidsvrijheid heeft bij de uitoefening van zijn taak. Deze beleidsvrijheid heeft de curator niet als hij gebonden is aan regels. Een van die regels is een verbintenisrechtelijke verplichting tot dulden of nalaten. Mijns inziens zorgt dit voor rechtsonzekerheid en zou de curator de bevoegdheid moeten hebben een verbintenis tot dulden of nalaten te beëindigen als hij deze beëindiging zelf in de hand heeft. Voor de curatoren van het Ruwaard van Puttenziekenhuis zou dat geen verschil maken, omdat de goodwillverplichting in de toelatingsovereenkomst niet was geformuleerd als verbintenis tot dulden of nalaten. In andere gevallen kan dit (beoogd) curatoren veel zorgen besparen. 